\title{
Gastrointgestinal Parasites of Tigers (Panthera tigris tigris) in Wayanad Wildlife Sanctuary, Kerala, India
}

\section{Moolamkudy Suresh Arjun ${ }^{1}$, Reghu Ravindran ${ }^{2 *}$, Arun Zachariah ${ }^{1}$, Mohanarangan Ashokkumar ${ }^{1}$, Anju Varghese ${ }^{2}$, Chundayil Kalarikkal Deepa ${ }^{2}$ and George Chandy ${ }^{1}$}

\author{
${ }^{1}$ Department of Wildlife Studies, Kerala Veterinary and Animal Sciences University, \\ Wayanad- 673576, Kerala, India \\ ${ }^{2}$ Departement of Veterinary Parasitology, College of Veterinary and Animal Sciences, \\ Kerala Veterinary and Animal Sciences University, Pookode, Lakkidi, P. O., \\ Wayand-673576, Kerala, India \\ *Corresponding author
}

\section{A B S T R A C T}

Keywords

Gastrointgestinal,

Tigers, Wayanad, Kerala.

Article Info

Accepted:

21 June 2017

Available Online:

10 August 2017
Studies on gastro-intestinal parasitic diversity of tigers in Wayanad Wildlife Sanctuary, Kerala, were conducted from April to September, 2015. Microscopical examination of scat samples were carried out to identify the gastro-intestinal parasitic diversity in the tiger (Panthera Tigris Tigris) population. Out of the 60 scat samples analyzed by sedimentation method, $46(76.6 \%)$ were positive for endoparasites. Ova of gastro-intestinal parasites belonging to seven different genera were identified. Spirometra sp. (71. 7\% or 39/46) was the most commonly recorded ova followed by Paragonimus westermani (54.3\% or 25/46). Although the gastro-intestinal parasitic diversity is less compared to similar studies from other tiger habitats, the number of individuals infected was considerably high.

\section{Introduction}

The science of faecal studies is called scatology or coprology. Scatological analysis provides information on diet composition, prey preferences, ecological significance, endoparasitic dynamics and health condition of animals (Seton, 1925; Patton et al., 1986).

Scat analysis is suggested as an easy, inexpensive and non-invasive method to understand the above mentioned parameters (Mukherjee et al., 1994). Faecal examination is a safe method to understand the parasitic conditions of free ranging wildlife (Marathe et al., 2002; Shirbhate, 2006).

When compared to other vertebrates, ecological studies on parasitic communities of large mammals are rare. It is also difficult to study the parasite dynamics of free ranging wildlife (Watve and Sukumar, 1995).Wild animals are more resistant to parasitic diseases under natural conditions, where 
animals have evolved in such a way that the parasites co-evolved with their hosts and would not cause much overt diseases in them (Gairola, 1986). It is important to study the parasitic dynamics in wild populations as it can transfer to domestic animals and even to the humans (Shirbhate, 2006).

Higher parasitic diversity and load is observed in carnivores as they feed on intermediate hosts of many parasites. When predators feed on highly parasitized prey individuals, the infective foci are regularly removed from the prey population, resulting in reduced transmission (Watve and Sukumar, 1995). It is important to study the parasitic dynamics in wild animals especially in predatory animals as parasites can significantly affect population growth of a species (Marathe et al., 2002).

A stable population of an apex predator indicates the stability of an ecosystem. Being an apex predator, the tiger, is considered as an indicator of healthy ecosystems. Significant decrease in tiger population can directly cause an imbalance in the ecosystem so that the need for conservation of tigers is critical (Varun, 2005).

Together with Nagarhole and Bandipur tiger reserves in Karnataka, Mudumalai tiger reserve in Tamil Nadu, the Wayanad Wildlife Sanctuary forms one of the largest tiger habitats in the world (Narasimen et al., 2013). The present study explored the endoparasite diversity in tiger populations of Wayanad Wildlife Sanctuary.

\section{Materials and Methods}

\section{Study area}

Wayanad is a part of the Western Ghats and the name Wayanad is derived from local name 'Vayal nadu' which means swampland. The Wayanad Wildlife Sanctuary occupies an area of $344.44 \mathrm{sq} \mathrm{km}$ and is comprised of two discontinuous units of $77.67 \mathrm{sq} \mathrm{km}$ (called WS-I) and $266.77 \mathrm{sq} \mathrm{km}$ (called WS-II). WSII falls in Sulthan Bathery Taluk of Wayanad revenue district and lies within geographic extremes of latitude $11^{\circ} 13^{\prime} \mathrm{N}-76^{\circ} 27 \mathrm{~S}$. WS-I falls in Mananthavady Taluk of Wayanad District and lies within latitudes $11^{\circ} 50^{\prime} \mathrm{N}-$ $11^{\circ} 59^{\prime} \mathrm{S}$ and longitudes $76^{\circ} 02^{\prime} \mathrm{E}-76^{\circ} 07^{\prime} \mathrm{W}$. Available record shows that the natural habitat continuity between WS-I and WS-II was completely broken, as a result of incessant encroachments in Pulpally vested forests in 1970's. However, the connectivity is maintained through Karnataka.

The Wayanad district occupies an area of $2131 \mathrm{sq} \mathrm{km}$ most of which is forested. Wayanad Plateau is situated at the confluence of three biologically distinct and diverse regions - the Western Ghats Mountains, the Nilgiri Hills and the Deccan Plateau.

The protected area is located on the eastern edge of Wayanad Plateau where it is contiguous with Protected Area network of Nagarhole and Bandipur Tiger Reserve of Karnataka in the north east and Mudumalai Tiger Reserve of Tamil Nadu in south east. The four together occupy an area of $2184 \mathrm{sq}$ $\mathrm{km}$, and is an integral part of Nilgiri Biosphere Reserve.

For management purposes, the sanctuary has a demarcated Core Zone (111sq km) mostly along the interstate forest boundaries and the remainder is the Buffer Zone (233sq km). The sanctuary is divided into four Forest Ranges viz, Muthanga, Sulthan Bathery, Kurichiat and Tholpetty. Wayanad Plateau has monsoon climate and based on the rainfall pattern, 3 seasons have been identified viz. dry season (January-April), first wet season (May August) and second wet season (September December). The evergreen forests of North and South Wayanad Forest Divisions are the 
highest rainfall regions of Kerala and South India. Annual rainfall ranges from $3000 \mathrm{~mm}-$ $4000 \mathrm{~mm}$.

The Wayanad Wildlife Division is contiguous with other protected areas of Karnataka and Tamil Nadu and it harbors the largest extant population of Asiatic elephants. The forest is also rich with its diverse flora and fauna and harbors a number of threatened and endemic species. Wayanad Wildlife Sanctuary has the highest tiger densities than any other protected areas of Kerala (Narayanan, 2009).

\section{Collection of tiger scats}

Samples for this study were collected under the supervision of Assistant Forest Veterinary Officer during study period from April to September, 2015 from Wayanad Wildlife Sanctuary. A total of 60 scat samples were collected randomly from different ranges of Wayanad Wildlife Sanctuary (Fig. 1). The samples taken for this study were confirmed to be tiger scats by the morphological characters.

Non-invasive methods were employed for the sample collection to determine the endoparasitic diversity. The scat samples were collected from Muthanga, Kurichiat, Bathery and Tholpetty Forest Ranges of Wayanad Wildlife Sanctuary. The samples were collected in 10 per cent formalin.

\section{Identification of ova of parasites}

Faecal ova were concentrated by sedimentation using centrifugation technique. The faeces (5-10 gm) was mixed with water in a mortar and triturated with the help of a pestle. The mixture was passed through a sieve to remove coarse debris. The filtrate was collected in a test tube and then centrifuged at $2000 \mathrm{rpm}$ for 3 minutes. The sediment was collected after discarding the supernatant. A drop of the sediment was taken on a glass slide and examined under the microscope. Parasitic ova were identified based on the morphological characters (Soulsby, 1982).

\section{Results and Discussion}

Results of gastrointestinal parasitic infections in tiger included the ova of trematodes, cestodes and nematodes (Table 1). Out of a total of 60 scats screened, 46 were positive for ova of different parasites (Fig. 7). Out of 46 positive samples $54.34 \%(25 / 46)$ were positive for Paragonimus westermani (Fig. 4) and was the only trematode ova observed. Cestode ova were observed in 39 out of 46 $(84.8 \%)$ positive samples. Among cestodes, ova of Spirometra sp. (71.7\%) (Fig. 2) and Taenia sp. (13.1\%) (Fig. 6) were observed. Nematode ova were seen in 10 out of 46 positive cases $(21.07 \%)$ which included the larvae (Fig. 3) of nematodes $2 / 46$ (4.3\%), ova of Toxocara sp. 2/46 (4.3\%), Strongyle sp. 4/46 (8.6\%) (Fig. 5) and Trichuris sp. 2/46 $(4.3 \%)$.

High level of parasitic infections can result in high mortality and morbidity in tigers through all age classes. In addition, loss of physical fitness and low reproduction capacity are also accompanied. Many of the human parasitic diseases have wild and domestic animals as reservoirs and transmitters. Parasites play a major role in wildlife diseases and in the dynamics of host populations (Kennedy, 1975; Grenfell and Dobson, 1995). Parasitic infections in wildlife populations can occur as epidemic outbreaks (e.g. micro parasites like bacteria, virus and protozoa) or as endemic proportions (e.g. macro parasite infection like nematodes, cestodes and arthropods) primarily causing host morbidity rather than host mortality. The two factors that influence the mortality are the virulence of the parasite and the host susceptibility that determines the reproductive rate of the infection (Roy and Robert, 1978). 


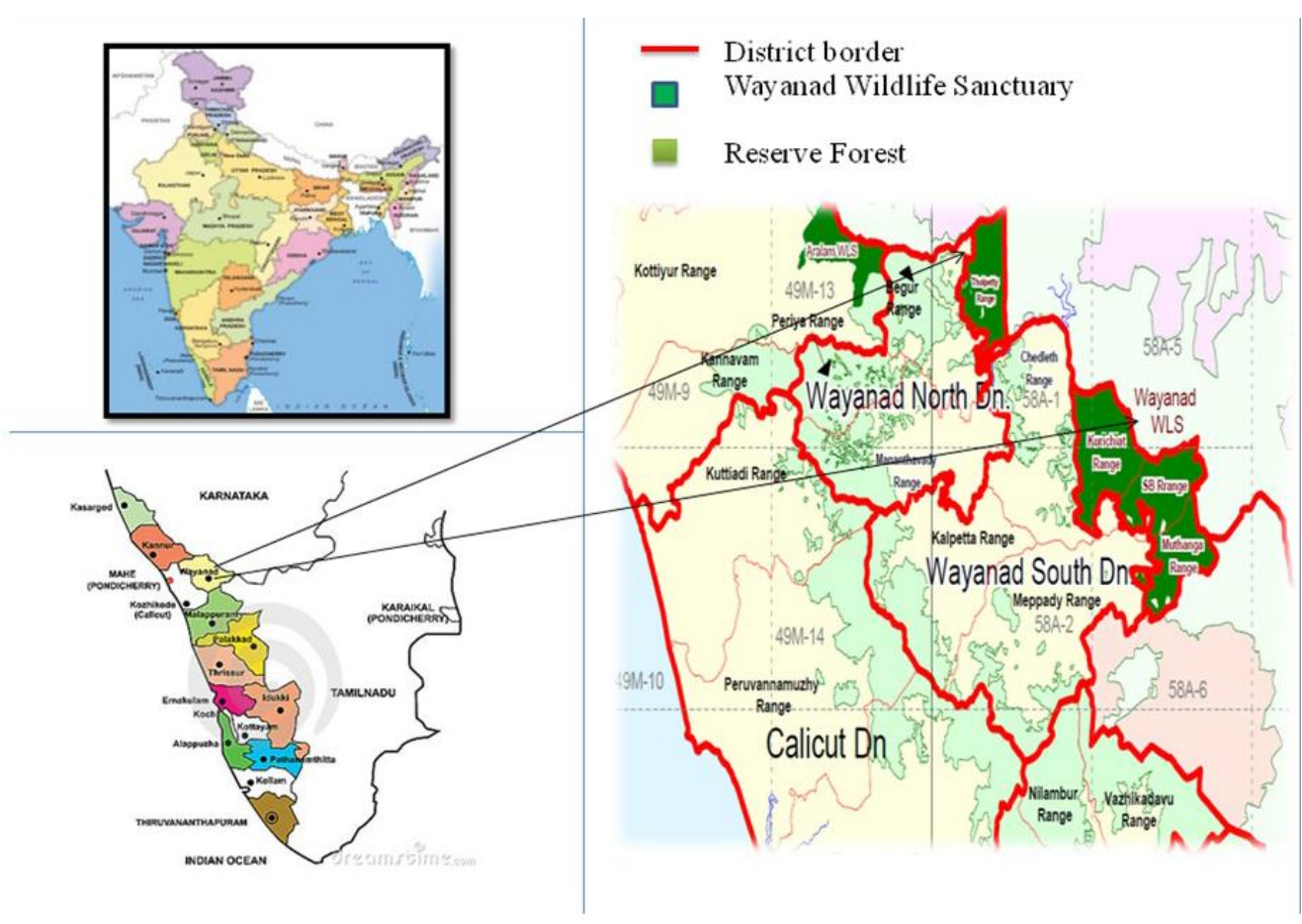

Figure.1 Map of Wayanad Wildlife Sanctuary

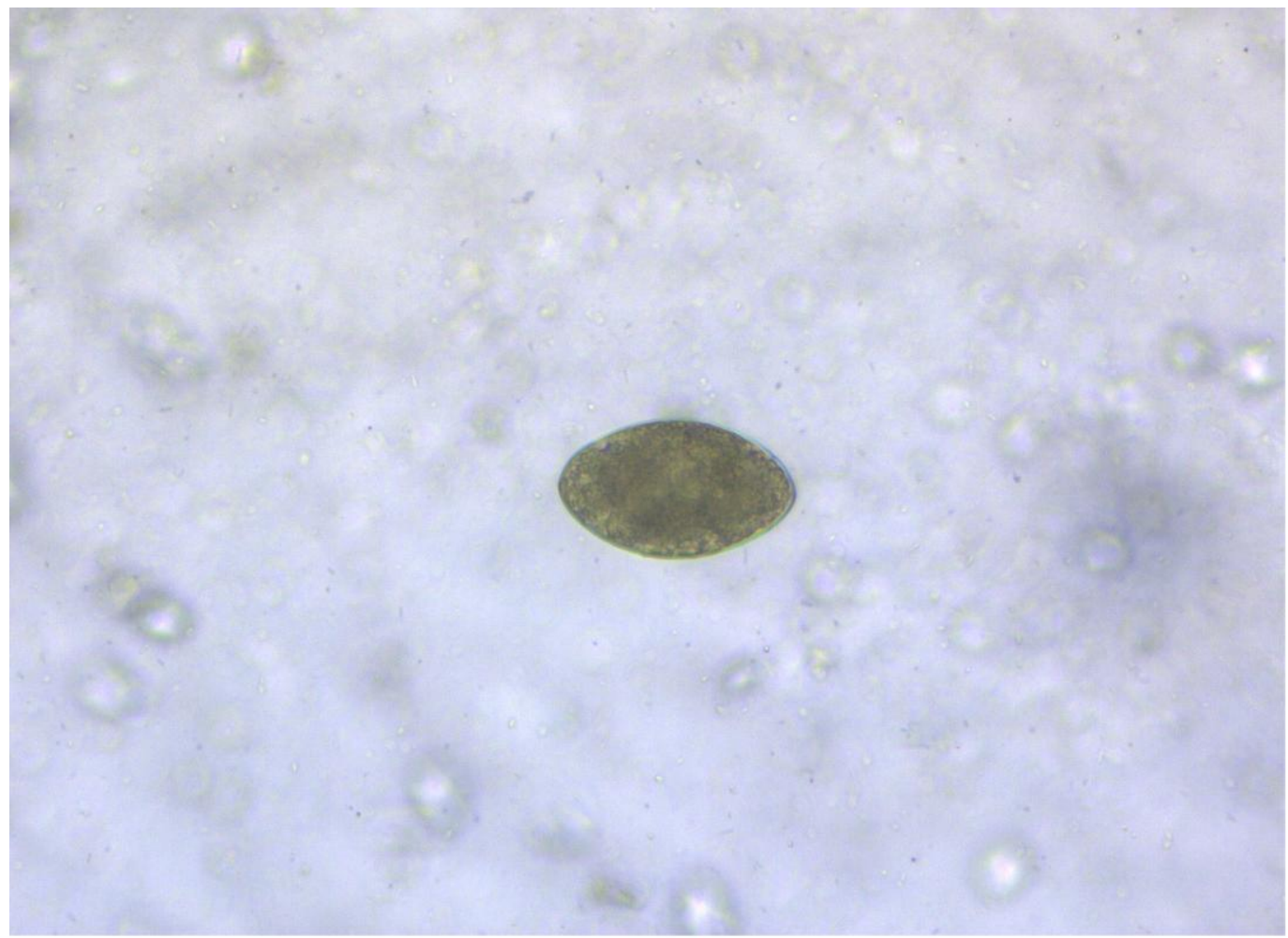

Figure.2 Ova of Spirometra sp.-(40x) 


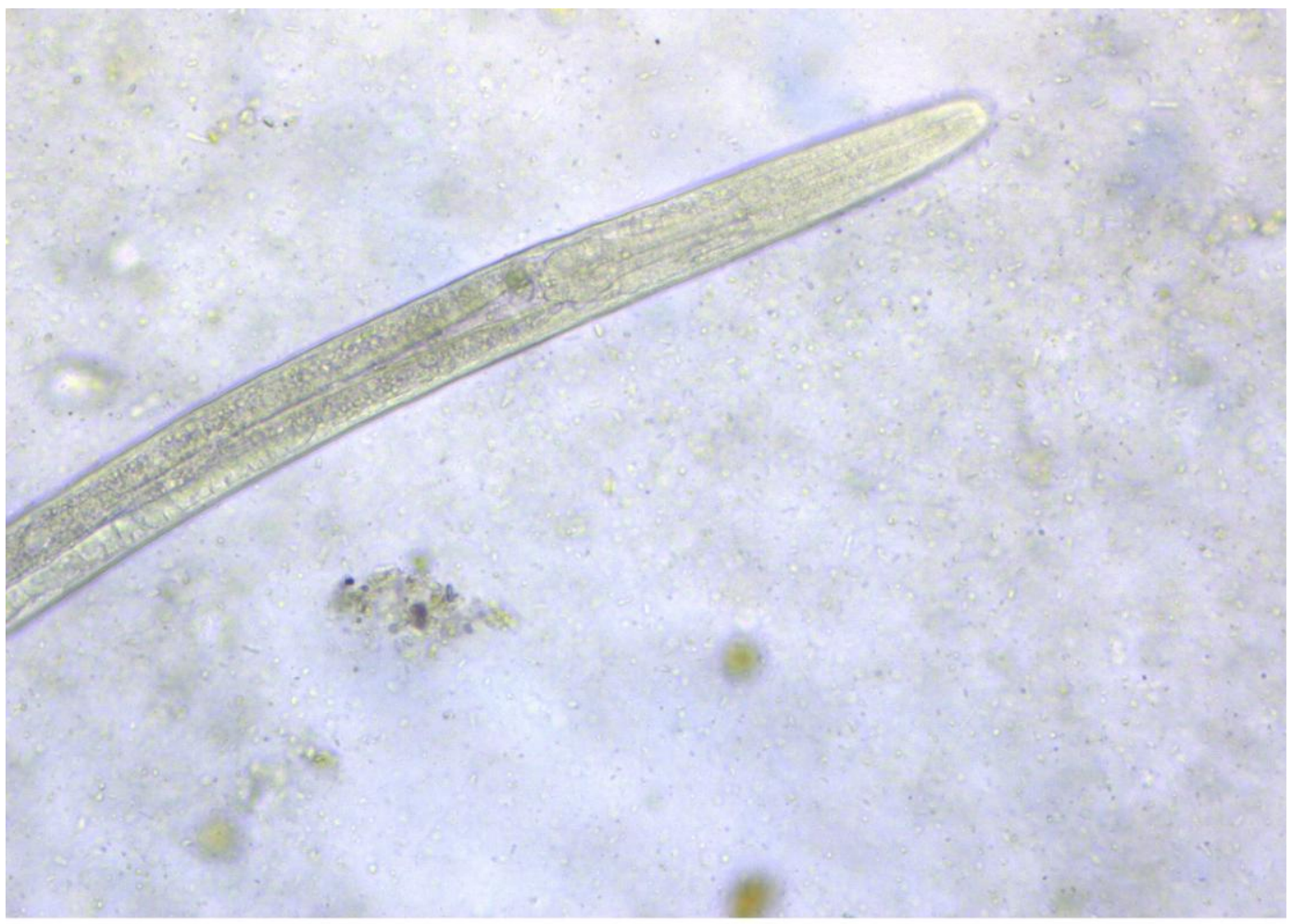

Figure.3 Larvae of unknown nematode (40x)

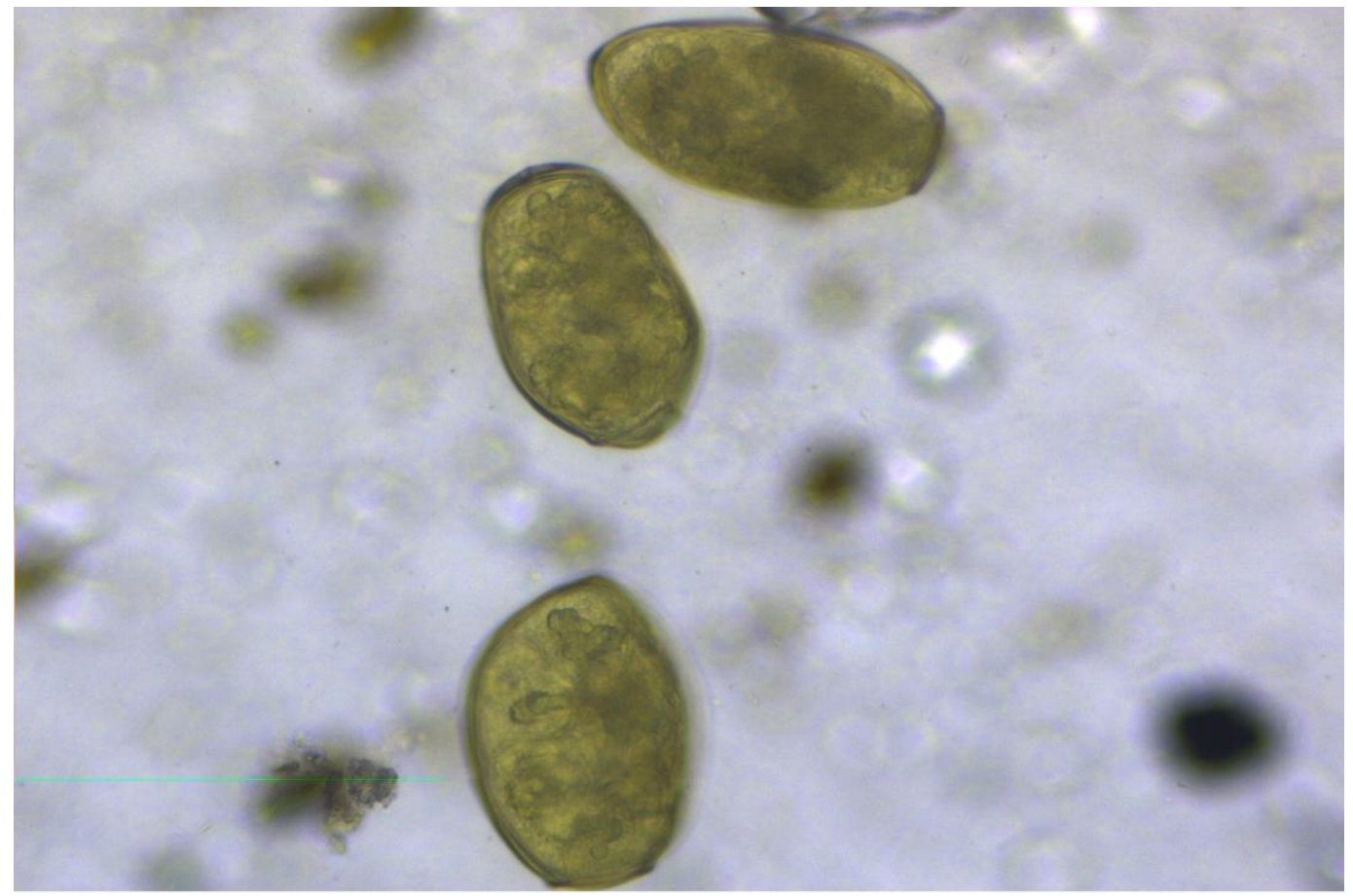

Figure.4 Ova of Paragonimus westermani $(40 \mathrm{x})$ 


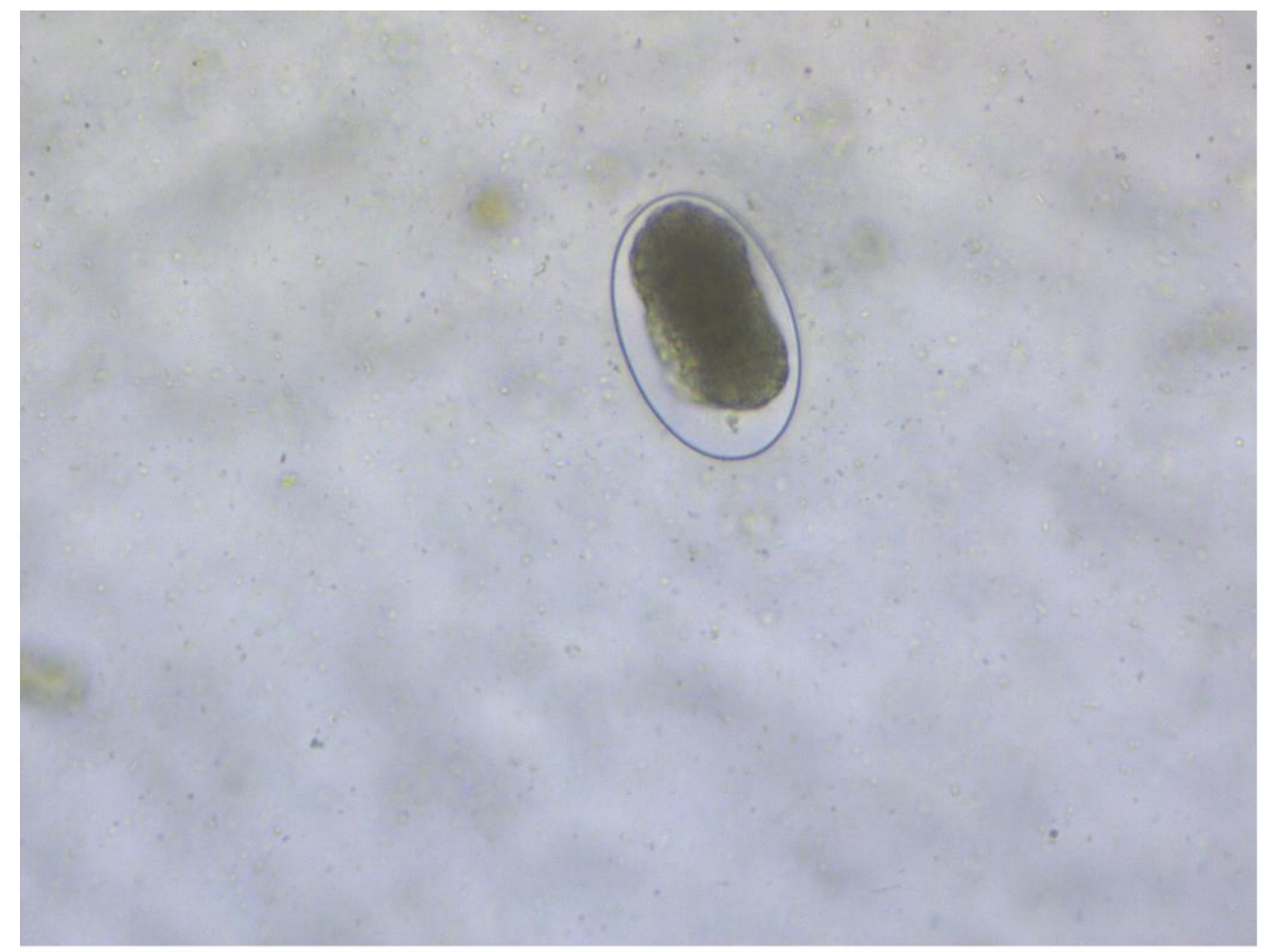

\section{Figure.5 Ova of Strongyle sp. (40x)}

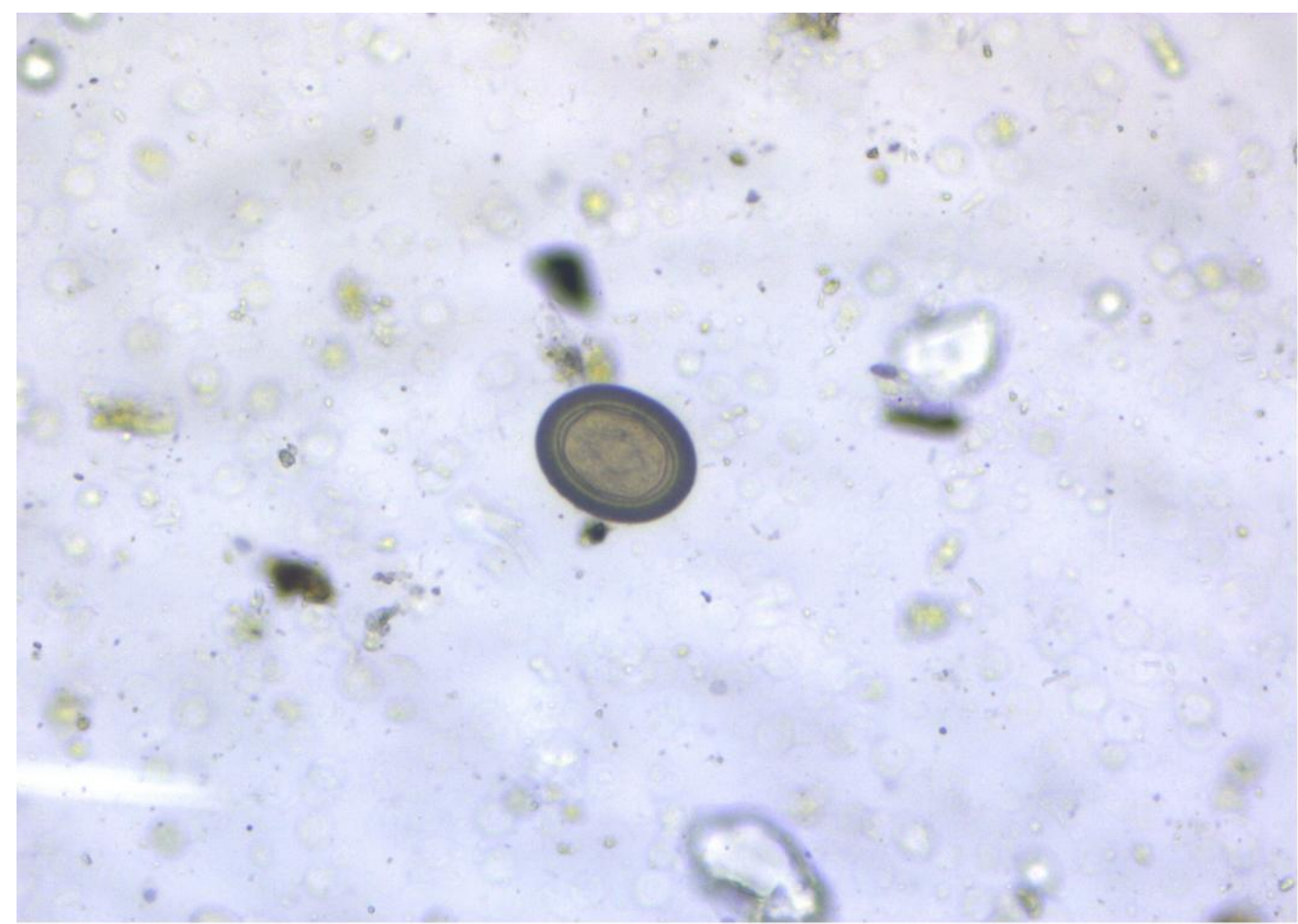

Figure.6 Ova of Taenia sp. (40x) 


\section{Percentage occurence (\%)}

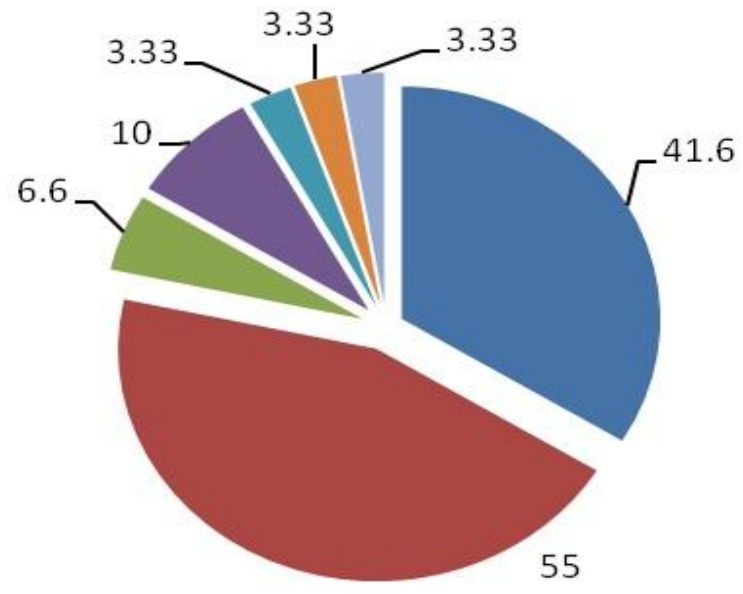

Paragonimus westermani

Diphyllobothrium latum

Strongyle sp.

Taeniasp.

Trichuris $s p$.

Toxocarasp.

Nematode larvae

Figure 7. Percentage occurrence of gastro-intestinal parasites recorded in Panthera tigris tigris from

Wayanad Wildlife Sanctuary during the study period

Table.1 Gastro-intestinal parasites recorded in Panthera tigris tigris from

Wayanad Wildlife Sanctuary

\begin{tabular}{|l|l|l|}
\hline \multicolumn{1}{|c|}{ Parasite } & \multicolumn{1}{c|}{$\begin{array}{c}\text { Number of positive samples out of } \\
\mathbf{6 0} \text { scat samples }\end{array}$} & \multicolumn{1}{|c|}{ Percentage (\%) } \\
\hline Paragonimus westermani & 25 & 41.6 \\
\hline Diphyllobothrium latum & 33 & 55 \\
\hline Strongyle sp. & 4 & 6.6 \\
\hline Taenia sp. & 6 & 10 \\
\hline Trichuris sp. & 2 & 3.33 \\
\hline Toxocara sp. & 2 & 3.33 \\
\hline Nematode larvae & 2 & 3.33 \\
\hline
\end{tabular}

The present study revealed the presence of parasitic ova in 76.6 per cent of the scat samples examined. Out of 60 scat samples examined, 46 were positive for parasitic infection and 14 samples were negative.

Being apex predators that have low predatory risk, the parasitic loads and diversity in tigers will be high when compared to other higher vertebrates. Ecological studies on parasitic communities of large mammals are comparatively few and it is very difficult to study the parasites of free-ranging wildlife. In the present study, seven different genera of parasites were recorded from tigers and the parasitic diversity is substantially less when compared to a similar study from Melghat Tiger Reserve (Shirbhate, 2006). This result cannot be used to generalize the parasitic diversity in tiger populations of the landscape, as only 60 scat samples could be examined during the study period.

The highest incidence of Spirometra sp. (71.7\%) followed by Paragonimus westermani $(54.34 \%)$ was observed in tigers. The second intermediate host of Spirometra sp. involves water snakes, alligators, tadpoles, birds and mammals. The occurrence of this parasite in tigers is to the consumption of the 
tissues of the intermediate hosts containing the infective stage of the parasite called as plerocercoid. Similarly, the infective stage of Paragonimus westermani is found in crabs and the crayfishes. The predation on lower carnivores like jungle cat (Felis chaus), Mongooses (Herpestes sp.), Leopard cat (Prionailurus bengalensis) etc. can result in parasitic infections in tigers as the lower carnivore diet includes fishes and crabs.

\section{References}

Gairola, H. K. 1986. Gastrointestinal parasites of zoo animals. Their impact, treatment and control. Wild life Health, 4: 4 - 9.

Grenfell, B. T. and Dobson, A. P. 1995. Ecology of infectious diseases in natural populations. Cambridge University Press, 7: 1-49.

Kennedy, C. R. 1975. Ecological animal parasitology. Oxford, Blackwell Scientific Publications, 142-148.

Marathe, R. R., Goels, S. S., Ranade, S. P., Jog, M. M. and Watve, M. G. 2002. Patterns in abundance and diversity of faecally dispersed parasites of tiger in Tadoba National Park, Central India. BMC Ecol., 2(1): 6.

May, R.M. and Anderson, R.M. 1978. Regulations and stability of hostparasite population interactions. $J$. Animal. Ecol., 47: 249-267.

Mukherjee, S., Goyal, S. P. and Chellam, R. 1994. Standardization of scat analysis techniques for leopard (Panthera pardus) in Gir National Park, Western India. Mammalia, 58 (1): 139 - 143.
Narasimen, R.K., Kumar, A.M., Jayam, P.P.C., Chinnaiyan, S., Nagarathinam, M. and Desai, A. A. 2013. Status of Tigers, Co-Predators and Prey in the Wayanad Wildlife Sanctuary, Kerala, India. WWF, India, 70p.

Narayanan, M. K. 2009. Floristic study of Wayanad district with special emphasis on conservation of rare and threatened flowering plants. PhD Thesis, University of Calicut, Calicut.

Patton, S., Rabinowitz, A., Radolph, S. and Johnson, S.S. 1986. A caprological survey of parasites of Neotropical Felidae. J. Parasitol., 72: 517 - 520.

Sergio, F., Caro, T., Brown, D., Clucas, B., Hunter, J., Ketchum, J. and Hiraldo, F. 2008. Top predators as conservation tools: ecological rationale, assumptions, and efficacy. Annu. Rev. Ecol. Evol. Syst., 39:1-19.

Seton, E.T. 1925. On the study of Scatology. J. Mammal., 6 (1): 47 - 49.

Shirbhate, M. V. 2008. Quantification of predation and incidence of parasitic infestation in Melghat Tiger Reserve with special reference to Tiger (Panthera Tigris Tigris). The Bioscan, 2 (2): $229-235$.

Soulsby, E. J. L. 1982. Helminths arthropods and protozoa of domesticated animals. Lea \& Febiger, Philadelphia, 7: 156239.

Watve, M.G. and Sukumar, R. 1995. Parasite abundance and diversity in mammals correlates with host ecology. Proc. Natl. Acad. Sci. U.S.A., 92 (19): 8945 - 8949.

\section{How to cite this article:}

Moolamkudy Suresh Arjun, Reghu Ravindran, Arun Zachariah, Mohanarangan Ashokkumar, Anju Varghese, Chundayil Kalarikkal Deepa and George Chandy. 2017. Gastrointgestinal Parasites of Tigers (Panthera tigris tigris) in Wayanad Wildlife Sanctuary, Kerala. Int.J.Curr.Microbiol.App.Sci. 6(8): 2502-2509. doi: https://doi.org/10.20546/ijcmas.2017.608.296 